\title{
ASUHAN KEPERAWATAN JIWA PADA KLIEN SKIZOFRENIA DENGAN RISIKO BUNUH DIRI
}

\author{
Itsnaini Wahyu Puspita Dewi", Erna Erawati \\ Program Studi Sarjana Terapan Keperawatan Magelang, Poltekkes Kemenkes Semarang, Jln Perintis Kemerdekaan \\ No. 78 Magelang, Jawa tengah, Indonesia 56115 \\ *itsnainiwpd@gmail.com
}

\begin{abstract}
ABSTRAK
Kesehatan mental merupakan sektor penting dalam mewujudkan kesehatan manusia secara menyeluruh. Berbagai solusi dapat dilakukan seseorang ketika muncul stressor, salah satunya bunuh diri. Beberapa orang menganggap bunuh diri adalah solusi yang tepat untuk menyelesaikan masalah. Bunuh diri merupakan tindakan yang secara sadar dilakukan oleh seseorang untuk mengakhiri kehidupannnya. Salah satu seseorang yang mempunyai resiko untuk melakukan bunuh diri adalah pasien skizofrenia. Perilaku bunuh diri terdiri dari tiga tingkatan yaitu ide/isyarat bunuh diri, ancaman bunuh diri, dan percobaan bunuh diri. Tujuan penelitian menggambarkan pengelolaan asuhan keperawatan skizofrenia dengan fokus studi risiko bunuh diri. Penelitian ini termasuk field research (penelitian lapangan) dengan menggunakan pendekatan deskriptif kualitatif, langkah-langkah yang dilakukan peneliti dalam penelitian ini yaitu wawancara, observasi, dokumentasi, dan reduksi data. Hasil penelitian ini menunjukkan bahwa pemberian asuhan keperawatan pada klien skizofrenia dengan risiko bunuh diri menunjukkan hasil yang signifikan adanya intervensi dari perawat sesuai dengan respon verbal dan non verbal klien.
\end{abstract}

Kata kunci: asuhan keperawatan, klien skizofrenia, risiko bunuh diri

\section{NURSING CARE FOR SCHIZOPHRENIA CLIENTS WITH RISK OF SELF-RISK}

\begin{abstract}
Mental health is an important sector in realizing overall human health. Various solutions can be done when someone appears stressor, one of them suicide. Some people consider suicide to be the right solution to solve a problem. Suicide is an act that is consciously carried out by someone to end his life. One person at risk for suicide is a schizophrenic patient. Suicidal behavior consists of three levels, namely suicide ideation / cues, suicide threats, and attempted suicide. The aim of the study is to describe the management of schizophrenia nursing care with a focus on suicide risk studies. This research includes field research using a descriptive qualitative approach, the steps taken by researchers in this study are interviews, observation, documentation, and data reduction. The results of this study indicate that the provision of nursing care to schizophrenic clients with suicide risk shows a significant result of the intervention of the nurse in accordance with the client's verbal and non verbal responses.
\end{abstract}

Keywords: nursing care, schizophrenia clients, suicide risk

\section{PENDAHULUAN}

Menurut Depkes (2011) prevalensi terjadinya masalah kesehatan jiwa meningkat secara tajam. Departemen Kesehatan Republik Indonesia (2011) menyatakan bahwa dalam kurun waktu 5 tahun orang dengan gangguan jiwa di Indonesia telah mencapai $11,6 \%$ dari 238 juta orang. Yang artinya sebanyak 26.180.000 penduduk Indonesia menderita gangguan jiwa.

Tingkat kematian yang disebabkan karena bunuh diri ini tidak hanya meningkat tajam di Indonesia, akan tetapi seluruh dunia. Karena begitu tingginya tingkat kematian yang disebabkan karena bunuh diri, setiap tanggal 10 Oktober diperingati sebagai ahri kesehatan mental. Data yang dirilis WHO
(2016) menunjukkan setiap 40 detik, seseorang kehilangan nyawa karena bunuh diri. Bunuh diri disebut juga sebagai fenomena global. Dan menurut Sulis (2019) faktanya 79\% bunuh diri dapat terjadi di negara-negara dengan pendapatan rendah dan menengah.

Tindakan percobaan bunuh diri ini dapat terjadi pada berbagai usia. Mulai dari remaja, dewasa, bahkan lansia juga terdapat kemungkinan untuk melakukan percobaan bunuh diri. Menurut Wilson (2012), beberapa penelitian telah mem-buktikan bahwa keinginan seseorang untuk melukai diri sendiri memiliki hubungan dengan tingginya kemungkinan untuk melakukan perilakunya. Keinginan ini sudah diperkirakan mempengaruhi 
perilaku untuk melukai diri sehingga kemungkinan keinginan melukai diri pun dapat mempengaruhi perilaku tersebut. Jadi kesimpulannya bahwa seseorang yang memiliki keinginan untuk melukai diri sendiri sangat mungkin berhubungan dengan bagaimana seseorang dapat mengontrol emosinya atau dapat memberikan sugesti untuk diri sendiri bahwa melukai diri dapat mengubah keadaan emosionalnya.

Berdasarkan UU Nomor 18 tahun 2014 tentang Kesehatan Jiwa, kesehatan jiwa didefinisikan sebagai kondisi dimana seseorang atau individu dapat berkembang dalam hal fisik, mental, spiritual, dan sosial. Sehingga individu tersebut menyadari kemampuan dari diri sendiri, dapat mengatasi tekanan, dapat bekerja secara produktif, dan mampu memberikan kontribusi untuk komunitasnya. Gejala yang menyertai gangguan ini antara lain berupa halusinasi, ilusi, waham, gangguan proses pikir, kemampuan berpikir, serta tingkah laku aneh, misalnya agresivitas atau katatonik. Menurut Balitbangkes Kemenkes RI (2013) gangguan jiwa berat dikenal juga dengan sebutan psikosis, dan salah satu contoh psikosis yaitu skizofrenia.

Data American Psychiatric Association atau APA (2013) menyebutkan 1\% dari populasi penduduk dunia menderita gangguan jiwa berupa Skizofrenia. Hal ini tentunya harus dapat dijadikan sebagai perhatian khusus bagi setiap individu untuk memperhatikan kesehatan mental dirinya masing-masing. Menurut Amelia (2013) rumah sakit jiwa di seluruh Indonesia ditempati oleh pasien dengan skizofrenia, yaitu sebanyak 90 $\%$.

Bunuh diri menurut Videbeck (2011) merupakan tindakan yang secara sadar dilakukan oleh seseorang untuk mengakhiri kehidupannnya. Perilaku bunuh diri adalah tindakan yang dilakukan secara sengaja untuk membunuh diri sendiri. Bunuh diri dapat melibatkan ambivalensi antara keinginan untuk hidup dan keinginan untuk mati. Perilaku bunuh diri terdiri dari tiga tingkatan yaitu berupa ide/isyarat bunuh diri, ancaman bunuh diri, dan percobaan bunuh diri .

Wood, Bellis, Mathieson dan Foster (2010) mengatakan bahwa terdapat beberapa kelompok risiko tinggi klien bunuh diri, antara lain seseorang dengan gangguan kepribadian, gangguan makan, depresi dan cemas, pengalaman hidup yang penuh stress, kemiskinan, serta riwayat keluarga dengan bunuh diri. Dari semua kelompok risiko tersebut, menurut Gomez-Duran, Martin-Fumado, Hurtado-Ruiz (2012) yang terbesar adalah kelompok gangguan jiwa berat, dan bunuh diri merupakan salah satu penyebab utama kematian klien skizofrenia dengan jumlah terbesar terjadi pada usia produktif dan laki-laki.

Penelitian yang dilakukan tanggal 21 Januari 2020 menunjukkan fakta bahwa di bangsal Sadewa RSJ Grhasia Yogyakarta terdapat klien skizofrenia dengan masalah keperawatan risiko bunuh diri. Tujuan penelitian ini yaitu untuk mengetahui bagaimana kriteria klien skizofrenia dengan risiko bunuh diri, dan mengetahui bagaimana keefektifan intervensi identifikasi pola koping yang dimiliki klien.

\section{METODE}

Metode yang digunakan dalam penelitian ini adalah metode deskriptif kualitatif dengan pemaparan kasus dan menggunakan pendekatan proses keperawatan dengan memfokuskan salah satu masalah penting dalam kasus yang dipilih, yaitu asuhan keperawatan pada klien Skizofrenia dengan fokus studi risiko bunuh diri.

Penelitian ini dilakukan di RSJ Grhasia Yogyakarta pada tanggal 21-25 Januari 2020, dalam penelitian ini menggunakan satu responden (klien) usia 48 tahun, bersedia menjadi responden, diagnosa medis Skizofrenia, klien dengan diagnosa keperawatan risiko bunuh diri, klien mampu diajak berkomunikasi. Kriteria pada penelitian ini yaitu diantaranya klien dalam keadaan dapat beraktivitas secara mandiri dan klien dapat berkomunikasi dengan baik. Pengumpulan data dilakukan dengan wawancara, observasi, dan mencari data melalui rekam medik responden. Data yang didapatkan dianalisis dengan mengamati data yang ada pada rekam medik klien, kemudian melakukan klarifikasi dengan melakukan wawancara dan observasi pada klien tersebut.

\section{HASIL}

Klien bernama Tn. W dengan umur 48 tahun, klien berjenis kelamin laki-laki, status perkawinan klien duda, beragama islam, dan pendidikan terakhir klien SLTA. Klien masuk RSJ Grhasia Yogyakarta pada tanggal 9 Januari 2020 dengan diagnosa medis F.20.0 (skizofrenia paranoid).

Alasan masuk Tn. W dibawa ke RSJ Grhasia Yogyakarta oleh keluarganya dikarenakan tibatiba klien berupaya bunuh diri. Terdapat beberapa 
alasan yang menyebabkan Tn. W melakukan percobaan bunuh diri bahkan sampai melakukan hal tersebut hingga dua kali. Terdapat dua faktor yaitu faktor predisposisi dan faktor presipitasi.

Faktor predisposisi merupakan faktor pendukung atau faktor yang menunjang terjadinya gangguan jiwa pada klien. Sedangkan faktor presipitasi merupakan faktor pencetus seseorang melakukan percobaan bunuh diri. Kedua faktor ini meliputi biologi, psikologi, dan sosial.

Faktor predisposisi dari Tn. W disebabkan karena mulai menunjukkan gangguan jiwa kurang lebih 1 tahun yang lalu. Klien dirawat di RSJ Grhasia Yogyakarta untuk kedua kalinya. Terakhir dirawat di RSJ Grhasia Yogyakarta pada tahun 2019. Dalam keluarga klien, tidak ada anggota keluarga yang memiliki riwayat gangguan jiwa. Klien merupakan anak ke-dua dari tiga bersaudara. Klien sudah berkeluarga, dan klien berperan sebagai seorang ayah dari 2 anaknya, laki-laki dan perempuan.

Selain itu, terdapat faktor presipitasi pada Tn. W yaitu klien putus obat selama kurang lebih dua bulan dan istri klien meminta cerai pada tahun 2019. Sehingga saat ini klien tinggal di rumah bersama ibu dan kakaknya.

Dari hasil pengkajian pada Tn. W yang berkaitan dengan persepsi bahwa klien bicara lambat, nyambung ketika diajak bicara, akan tetapi klien sulit mengawali pembicaraan. Klien mengatakan menyukai semua anggota tubuhnya meskipun terdapat bekas luka pada pergelangan tangan kanan dan kiri, bahkan klien merasa bersyukur terhadap dirinya sendiri. Klien memiliki perasaan gagal, tidak berguna, dan merasa hidupnya tidak bahagia. Klien juga mengatakan ingin segera sembuh dan pulang untuk berkumpul kembali bersama keluarga.

Klien kooperatif ketika dilakukan wawancara, namun kontak mata kurang, karena klien lebih cenderung untuk memandang satu titik bukan memandang lawan bicaranya. Penampilan dalam berapakaian klien rapi dan sesuai dengan pakaian yang dianjurkan pihak rumah sakit. Klien dapat beraktivitas secara mandiri tanpa bantuan meskipun secara perlahan-lahan.

Berdasarkan pengkajian yang dilakukan tanggal 21 Januari 2020 pukul 15.00 pada Tn. W, didapatkan analisa data sebagai berikut: Data Subjektif (DS) klien mengatakan pernah melakukan percobaan bunuh diri sebanyak dua kali dengan menggunakan tali. Klien juga mengatakan bahwa dirinya merasa tidak bahagia karena hidupnya monoton. Data Objektif (DO) klien bicara lambat, kontak mata kurang karena klien cenderung memandang satu titik, bukan memandang lawan bicaranya. Maka diagnosa keperawatan yang didapat berdasarkan pengkajian yang telah dilakukan pada Tn. W yaitu Risiko Bunuh Diri (RBD).

Tindakan keperawatan yang akan dilakukan berdasarkan pengkajian yang telah dilakukan kepada Tn. W pada tanggal 21 Januari 2020, peneliti menyusun tujuan dan rencana tindakan keperawatan untuk mengatasi masalah risiko bunuh diri adalah sebagai berikut. Tujuannya yaitu klien dapat mengetahui pola koping yang dapat diterapkan dan agar klien menerapkan pola koping dalam kegiatan sehari-hari. Karena biasanya ketika klien menghadapi masalah, klien hanya diam dan jarang bercerita kepada keluarganya, bahkan orang lain.

Dari masalah keperawatan risiko bunuh diri yang dialami Tn. W, peneliti membuat beberapa rencana tindakan keperawatan yang akan dilakukan yaitu identifikasi pola koping yang bisa diterapkan, nilai pola koping yang bisa dilakukan, dan anjurkan klien menerapkan pola koping konstruktif dalam kegiatan sehari-hari. Selain rencana tindakan keperawatan tersebut, peneliti juga akan melakukan evaluasi tindakan yang telah dilakukan sebelumnya, yaitu strategi pelaksanaan II risiko bunuh diri terkait identifikasi aspek positif yang dapat dilakukan klien.

Ketika dilakukan tindakan keperawatan yang membahas pola koping, klien kooperatif, klien tampak dapat memahami topik pembicaraan, kontak mata kurang. Klien juga dapat mengetahui pola koping apa yang ingin diterapkan dalam kehidupan sehari-hari ketika menghadapi suatu masalah.

Hasil evaluasi yang didapatkan berdasarkan tindakan keperawatan sesuai intervensi yang telah dibuat peneliti yaitu pada $\mathrm{Tn}$. W diperoleh data subjektif (DS): klien mengatakan lebih senang dan lega dapat mengetahui pola koping yang dapat diterapkan yaitu dengan cara apabila memiliki suatu masalah klien akan cerita kepada ibunya. Klien mengatakan memahami topik pembicaraan tentang pola koping yang bisa dilakukan. Klien mengatakan akan berusaha untuk menerapkan pola koping dalam kegiatan sehari-hari. Data Objektif (DO): klien kooperatif ketika berinteraksi, klien mampu menjawab sesuai 
dengan pertanyaan, klien masih sulit memulai pembicaraan. Analisa: masalah SP (strategi pelaksanaan) 3 RBD (identifikasi dan nilai pola koping yang bisa dilakukan) teratasi. Perencanaan: lanjutkan SP (strategi pelaksanaan) 4 RBD (rencanakan masa depan).

\section{PEMBAHASAN}

Pembahasan difokuskan pada aspek proses asuhan keperawatan mulai dari pengkajian, analisa data, perumusan masalah, rencana tindakan keperawatan, pelaksanaan tindakan keperawatan, dan catatan perkembangan yang berkaitan dengan risiko bunuh diri. Klien dengan risiko bunuh diri ini diharapkan mendapatkan bantuan dan perawatan yang intensif, karena risiko bunuh diri ini merupakan salah satu kedaruratan psikiatri. Menurut Trent (2013) kedaruratan psikiatri merupakan gangguan yang sifatnya akut, baik pada perilaku, pikiran, atau hubungan sosial yang membutuhkan intervensi segera yang didefinisikan oleh klien, keluarga klien, atau masyarakat. Berdasarkan hasil penelitian dari Wardaningsih (2010) terkait gambaran strategi koping keluarga ketika merawat pasien dengan skizofrenia di wilayah Kecamatan Kasihan Bantul, terdapat beberapa faktor yang dapat memengaruhi strategi koping keluarga yaitu antara lain faktor keuangan, keyakinan, dukungan sosial, faktor pengetahuan dan komunikasi.

Dalam penelitian terkait perawatan pada pasien skizofrenia yang berpotensi bunuh diri, ada beberapa penelitian yang bisa menjadi rujukan, berikut adalah beberapa penelitian yang masih ada hubungannya dengan penelitian ini:

Penelitian yang dilakukan oleh Nur Aulia, Yulastri, Heppi Sasmita dengan judul "Analisis Hubungan Faktor Risiko Bunuh Diri Dengan Ide Bunuh Diri Pada Remaja". Hasil penelitiannya menunjukkan bahwa risiko bunuh diri pada remaja faktor psikologis dan faktor biologi memiliki hubungan yang signifikan terhadap ide bunuh diri remaja. Sementara untuk faktor keluarga,faktor lingkungan, faktor riwayat bunuh diri, faktor sorientasi seksual tidak terdapat hubungan yang signifikan dengan ide bunuh diri remaja. Faktor dominan yang memiliki hubungan erat dengan ide bunuh diri adalah faktor psikologis.

Penelitian yang dilakukan oleh Khusnul Aini1, Mariyati, dengan judul "Pengalaman Perawat Unit Perawatan Intensif Psikiatri Dalam Merawat Klien Dengan Risiko Bunuh Diri". Penelitian tersebut menunjukkan bahwa terjadi peningkatan kasus risiko bunuh diri pada pasien yang di rawat di ruang perawatan intensif psikiatri, berkisar $30-50 \%$ dalam satu tahun terakhir. Didapatkan lima tema yang didapatkan dari pengalaman perawat dalam merawat pasien dengan risiko bunuh diri, yaitu penemuan kasus, perlindungan keselamatan pasien, motivasi yang diberikan perawat, upaya melibatkan keluarga dalam perawatan, serta kendala yang hadapi perawat dalam merawat pasien dengan risiko bunuh diri.

Penelitian yang dilakukan oleh Irene Febriany Mamo Kitu, Meidiana Dwidiyanti, Diyan Yuli Wijayanti dengan judul "Terapi Keperawatan Terhadap Koping Keluarga Pasien Skizofrenia". Penelitian tersebut menunjukkan bahwa Koping keluarga yang baik akan berdampak baik bagi kondisi anggota keluarga yang menderita skizofrenia. Terapi generalis, terapi spesialis dan terapi komplementer dapat membantu meningkatkan koping keluarga agar keluarga dapat menghadapi situasi penuh tekanan yang terjadi dan tetap berusaha membantu proses penyembuhan anggota keluarga yang mengalami gangguan jiwa.

Berdasarkan beberapa judul yang mempunyai keterkaitan dengan judul penelitian ini tidak ada yang membahas tentang "Asuhan Keperawatan Jiwa Pada Klien Skizofrenia dengan Risiko Bunuh Diri”, yaitu penelitian yang mengaitkan antara klien skizofrenia dengan resiko bunuh diri, maka dengan itu peneliti tertarik untuk melakukan penelitian tentang fenomena tersebut. Manajemen krisis merupakan suatu tindakan preventif yang tujuannya dapat mencegah terjadinya perilaku bunuh diri. Hal ini digunakan sebagai dasar perlunya pemberian terapi sebagai upaya tindakan preventif dari klien dengan bunuh diri.

Sejak dilakukan pengkajian, klien menyadari bahwa dirinya berada di RSJ Grhasia Yogyakarta dikarenakan pernah melakukan pecobaan bunuh diri sebanyak dua kali, yang artinya klien tidak menyangkal dengan apa yang telah terjadi pada diri sendiri. Ketika dilakukan proses tindakan keperawatan, klien terlihat lebih senang dan klien juga mau terbuka untuk bercerita mengenai masalah-masalah yang dihadapi. 
Klien juga sedikit demi sedikit mau untuk memulai pembicaraan. Dengan dilakukannya tindakan keperawatan pada klien, diharapkan klien dapat dibantu oleh pihak keluarga dan kerabat untuk bisa menyalurkan tindakan positif ketika klien memiliki stresor, salah satunya melalui dukungan psikologis pada klien.

\section{SIMPULAN}

Perilaku percoban bunuh diri sering terjadi, baik di kalangan remaja, dewasa, ataupun lansia. Perilaku ini tidak hanya meningkat tajam di Indonesia saja, akan tetapi hampir seluruh dunia. Sebelum dilakukan tindakan pada Tn. W, klien kooperatif, tidak menyangkal adanya percobaan bunuh diri. Akan tetapi klien bicara lambat dan sulit memulai pembicaraan. Klien juga belum paham dengan pola koping yang dapat diterapkan ketika klien menghadapi suatu masalah.

Setelah diberikan asuhan keperawatan dengan intervensi identifikasi pola koping yang dapat diterapkan, peneliti menganggap hal ini efektif karena klien dapat mengetahui bagaimana cara atau pola koping yang dapat diterapkan ketika klien menghadapi masalah. Seperti yang dikatakan klien, klien akan terbuka atau bercerita tentang masalah tersebut kepada orang yang dipercayainya, yaitu ibunya. Sehingga penelitian ini menunjukkan bahwa pemberian asuhan keperawatan pada klien skizofrenia dengan risiko bunuh diri menunjukkan hasil yang signifikan adanya intervensi dari perawat sesuai dengan respon verbal dan non verbal klien

\section{DAFTAR PUSTAKA}

Aini, Khusnul \& Mariyati. (2020). Pengalaman Perawat Unit Perawatan Intensif Psikiatri dalam Merawat Klien dengan Risiko Bunuh Diri. Jurnal Keperawatan Jiwa, 8(1), 8996.

Amelia, D.R., \& Anwar Z. (2013). Relaps pada Pasien Skizofrenia. Jurnal Ilmiah Psikologi Terapan, 1(1), 53-65.

American Psychiatric Association. (2013). Diagnostic and statistical manual of mental disorders (DSM-5®). American Psychiatric Pub.

Aulia, N., Yulastri, Heppi Sasmita. (2019). Analisis Hubungan Faktor Risiko Bunuh Diri dengan Ide Bunuh Diri pada Remaja. Jurnal Keperawatan, 11(4), 307-314.
Balitbangkes Kemenkes RI. (2013). Riskesdas 2013.

Depkes. (2011). Program Kesehatan Jiwa.

Gomez-Duran, E.L, et al. (2012). Clinical and Epidemiological Aspects of Suicide in Patients with Schizoprenia. ActasEspPsiquiatr 2012;40(6):333-45.

Kitu, I. F. M., Meidiana D., Diyan Y.W. (2019). Terapi Keperawatan terhadap Koping Keluarga Pasien Skizofrenia. Jurnal Keperawatan Jiwa, 7(3), 253-256.

Nurjanah, Siti. (2013). Manajemen Kasus Spesialis Keperawatan Jiwa pada Klien Risiko Bunuh Diri dengan Pendekatan Teori Chronic Sorrow di Ruang Utari Rumah Sakit Marzoeki Mahdi Bogor Tahun 2013.

Trent James. (2013). A Review of Psychiatric Emergencies", CME Resource, Sacramento, California.

Videbeck, S.L..(2011). Buku ajar keperawatan jiwa. (Renata Komalasari, $d k k$, penerjemah). Jakarta : EGC.

Wardaningsih S., Rochmawati E., Sutarjo P. (2010). Gambaran Strategi Koping Keluarga dalam Merawat Pasien Skizofrenia di Wilayah Kecamatan Kasihan Bantul. Mutiara Medika, 10(1), 55-61.

Widianti, E., Budi Anna K., Ice Y. W. (2017). Jurnal Pendidikan Keperawatan Indonesia, 3(1), 83-99.

Wilson, F. L. (2012). Thoughts, images, and rumination of self-harm: validating a new measure of non-suicidal self-injury (NSSI) ideation.

Winurini, Sulis. (2019). Pencegahan Bunuh Diri di Indonesia. Jurnal Bidang Kesejahteraan Sosial, XI(20), 13-18. 
Jurnal Keperawatan Jiwa Volume 8 No 2 Hal 211 - 216, Mei 2020

FIKKes Universitas Muhammadiyah Semarang bekerjasama dengan PPNI Jawa Tengah 